\title{
En los 500 años del descubrimiento: Colones y Pinzones de la microbiología
}

\author{
WALTER LEDERMANN D.
}

\section{In the five hundred years of the Discovery: Colones and Pinzones of the Microbiology}

En 1992 se han completado quinientos años de gloria para Cristóbal Colón. Pero... ¿toda para él y nada para los otros? Hubo predecesores, hubo quienes compartieron sus ideas y quienes lo orientaron y hasta lo acompañaron en su aventura. Al celebrar los cinco siglos del gran descubrimiento nos vienen a la mente situaciones similares, no en el campo geográfico, sino en el de nuestra especialidad médica. Parker y Leikind ${ }^{1}$ sostienen que, en este terreno, hay muchos que recolectan perlas ("cuentas" dicen ellos) y muy pocos que las ensartan para formar un collar. Recordando el 12 de octubre de 1492, preferimos hablar de Colones y de Pinzones, para referirnos a quienes hicieron los grandes descubrimientos o invenciones y a los que contribuyeron con sólo una perla al avance de la ciencia, respectivamente. Por ahora, a fin de no aburrir al lector, contentémonos con el terreno de la microbiología y con citar apenas algunos ejemplos escogidos.

Roberto Koch fue, sin duda, un Colón. Sin embargo, como si todos sus hallazgos no bastaran a su gloria, suelen atribuírsele, ligeramente, algunos que no hizo. Entre ellos, el de los medios de cultivo sólidos, que permitieron un avance fabuloso de la microbiología, proporcionando un substrato para el fácil aislamiento e identificación de las distintas especies de un cultivo polimicrobiano. Aquí la lista de los Pinzones es extensa, comenzando por Bartolomeo Bizio, quien en 1823 describió, aunque erróneamente, la especie bacteriana de nombre más antiguo en la actualidad: Serratia marscecens. Para aislar el principio infeccioso que producía el prodigio de "la polenta sangrienta", Bizio utilizó trozos de papa, que le permitieron ver cómo la colonia bacteriana -que él estimaba un hongo- enrojecía progresivamente y luego se marchitaba. Casi treinta años después, Ehrenberg lograría revivir la Serratia en un pedazo de carne seca, que inoculó en papa hervida y luego en rebanadas de pan y de queso ${ }^{3}$. El gran avance vino con Colón... perdón, con Koch, quien, buscando una substancia con la cual solidificar sus caldos, dio con la gelatina. Koch tenía la visión genial de lo que significaría un medio sólido para el desarrollo de la bacteriología y buscaba directamente su camino a las Indias. Dio con el sendero equivocado, porque la gelatina se licuaba a los 35 grados de la estufa de cultivo, en tanto que algunas bacterias capaces de crecer a 22 grados, temperatura que permitía su soli- dificación, se la "comían" con sus enzimas proteolíticas.

En este momento aparecen los Pinzones, en este caso marido y mujer: el matrimonio Hesse. Walter Hesse fue un inquieto médico alemán, quien habiendo "hecho una pasadita" por laboratorio de Koch, quedó tan entusiasmado con la bacteriología que, de vuelta a casa, se puso a estudiar las bacterias que pululaban por el aire de su estudio. Frau Hesse, diligente y abnegada, se esforzaba en la cocina preparando los caldos para las bacterias y la sopa para su marido, con las necesarias diferencias culinarias. Escuchando como éste se quejaba de su incapacidad para aislar los minúsculos seres del aire, la señora recordó una vieja receta de su madre, que ésta había conocido por unos amigos holandeses que un tiempo vivieran en Java. Allí se usaba, en lugar de gelatina, el agar-agar (el alga japonesa Gelidium corneum) para hacer jaleas y embellecer entradas y postres, un producto que no se fundía a la temperatura bacteriológica de 35-37 grados.

- ¡Pero si lo has usado por años en tus postres! exclamaría Walter Hesse.

- ¡Oh, mein liebe Mann -respondería ella, con esa graciosa inconsciencia femenina- ...pero si nunca me preguntaste!

El Dr. Hesse quedó fascinado con el descubrimiento y se supone que, hacia fines de 1881 , debe haber escrito al maestro al respecto, pues en $1882 \mathrm{el}$ agar se menciona en la histórica comunicación de Koch a la Academia anunciando el descubrimiento del Mycobacterium ${ }^{4}$. Sin duda ni Hesse ni Koch pensaron que este descubrimiento doméstico merecería autoría o reconocimiento para una simple ama de casa. Koch incorporó la nueva técnica como propia y silenció el nombre de la señora Fanny Eilshemius. Parker y Leikind, citados al comienzo de este artículo, hicieron una investigación tenaz para rescatar este nombre del olvido y hasta obtuvieron una foto del matrimonio Hesse, que no podemos publicar sin su autorización. Fanny Eilshemius nació en New Jersey, EE.UU., en 1850, hija de un inmigrante alemán llegado en 1818. A los 24 años viajó a Europa y en Alemania conoció a quien sería su marido, por entonces médico del distrito de Schwartzenberg. Ya convertida en Frau Hesse, ayudó en el laboratorio al doctor e ilustró sus trabajos. Olvidada e ignorada, Fanny Eilshemius falleció en 
1934 y nos preguntamos, al igual que Parker y Leikind: ¿si descubrimientos e invenciones menores son recordados con el nombre de su autor, no sería justo que, en lugar de hablar de "agar corriente", dijéramos "agar Frau Hesse"?

Un descubrimiento menor que ha perpetuado el nombre de su autor es la "placa de Petri". ¿Acaso el contenedor (la placa) es más importante que el contenido (el agar)? ¿Qué sabemos de Petri? Lo creíamos italiano, pero fue uno de tantos bacteriólogos alemanes de la época de oro de la bacteriología: Julius Richard Petri (1852-1921). Ignoramos sus otros aportes a la ciencia y no podemos saber si, como Kitasato, quedó marcado por una invención menor. Shibasaburo Kitasato (1852-1931) fue un distinguido bacteriólogo japonés que trabajó en Berlín con Ehrlich y Behring, publicando con este último el clásico trabajo sobre inmunización antitetánica ${ }^{5}$. Fue también el primero en aislar el Clostridium tetani en cultivo puro y contribuyó a la producción de la antitoxina diftérica; una pirueta del destino quiso, empero, que el grueso de los microbiólogos lo recuerde sólo por un "acto menor": el diseño de un matraz Erlenmayer con una salida lateral bajo el gollete, conocido como "matraz Kitasato".

Más afortunado, el francés Pierre Paul Emile Roux (1853-1933) fue todo un Colón en sus trabajos sobre la antitoxina diftérica y su memoria no necesita para nada la "placa de Roux", una curiosa botella aplastada que se usa en la producción del toxoide. Olga G. Povitzky diseñó en 1929 una placa mucho más grande, que inmortalizó su nombre ${ }^{6}$; conocemos la placa, pero ignoramos mayormente el resto de su aporte científico.

Las placas de Roux y de Povitzky tienen un uso muy restringido en bacteriología, en tanto que un instrumento mucho más utilizado no conservó el nombre de su autor: el asa de platino o asa graduada para hacer recuento de colonias, diseñada por Walter Kruse (1864-1943), aquel bacteriólogo alemán que atestiguó contra Emmerich en el juicio del Gelsenkirchen?

¿Cómo calificar a Hans Christian Joachim Gram (1853-19389) sino como un Colón? Buscando una tinción que permitiera distinguir a las bacterias en biopsias de tejidos, descubrió todo un nuevo mundo, el método capital para diferenciar grandes grupos bacterianos por microscopia. En todos los textos clásicos encontramos apenas una mísera referencia: Gram, bacteriólogo danés... Pero... ¿quién fue este Gram y cómo llegó a su descubrimiento? Era un investigador cincuentón que trabajaba en el laboratorio del sabio alemán Carl Friedlander, el descubridor de la Klebsiella pneumoniae, hasta hace poco llamada "bacilo de Friedlander". Investigando la etiología de la neumonía lobar, este autor creía haber encontrado al agente causal en este bacilo, ya visualizado ocho años antes por Klebs, pero fue públicamente refutado por Fraenkel en el Tercer Congreso de Medicina Interna, en Berlín, 1884, quien propuso al neumococo como el agente de die genuine Pneumonie.

Esto dio comienzo a una ácida polémica. Hoy parece inconcebible, dice Robert Austrian, "la" autoridad mundial en neumococo ${ }^{8}$, confundir esta bacteria con una Klebsiella, pero entonces... Gram aún nada había dicho. Friedlander había mencionado la técnica de su ayudante en una publicación de 1883, sin valorizarla ni saber que terminaría por dar la razón a su rival. Gram hizo su propia publicación el 15 de marzo de $1884^{9}$, en la cual, entre otras cosas, analizó veinte cultivos aislados por Friedlander de casos fatales de neumonía lobar. Todos era capsulados y diecinueve de ellos retuvieron la coloración, mientras sólo uno se destiñó: este curioso coco (recordemos que la Klebsiella puede presentar formas muy cortas) era en realidad el único bacilo de Friedlander, en tanto que los otros diecinueve eran neumococos de Fraenkel. Sin embargo, pasó un año, en el que aparecieron los decisivos trabajos de Weichselbaum sobre la neumonía lobar, antes que Friedlander reconociera hidalgamente que estaba en un error, que la inmensa mayoría de las neumonías eran causadas por el neumococo de Fraenkel, que retenía la tinción de Gram, en tanto que sólo una minoría excepcional se debía a su propio bacilo, que no retenía el Gram.

En los años siguientes la utilidad de la técnica se hizo evidente, hasta que en 1889 , en la famosa serie de los Précis de ..., que publicaba la editorial Mason et fils en París, en el de Microbiología se recomienda someter a todos los cultivos a la tinción de Gram, como primera orientación diagnóstica ${ }^{10}$. Con este único aporte, Hans C. J. Gram entraba en la galería de los inmortales.

De la misma manera lo hicieron Franz Ziehl (18571926) y Friedrich Karl A. Neelsen (1854-1894) con su famosa tinción para la baciloscopia. No se pusieron de acuerdo, no hicieron publicación alguna al respecto y probablemente nunca se conocieron. Para colmo, su fama es equívoca, pues la tinción, en estricto rigor, es mérito de Paul Ehrlich. Koch teñía su bacilo con azul de metileno alcalino, seguido por la tinción de Bismarck, método que, de acuerdo a la insidiosa afirmación de Loeffler, el famoso sabio habría descubierto por accidente. Sin embargo, no era una tinción diferencial ni selectiva. El genial Ehrlich fundamentó su método en el carácter alcohol-ácido resistente del bacilo tuberculoso, utilizando ácido nítrico y coloreando con violeta de genciana o con fucsina, fortificadas por la presencia de anilina disuelta en agua.

Paul Ehrlich comunicó su descubrimiento el 1 de mayo de 1882, fecha en que comienza la insólita historia de la "tinción de Ziehl-Neelsen". Ziehl prácticamente no aportó nada, proponiendo tan sólo emplear ácido carbólico en lugar de anilina, alternativa que ya había manejado el propio Ehrlich. En cuanto a Neelsen, cambió la genciana por fucsina, también una alternativa del autor, y el ácido nítrico por sulfúrico, su única innovación real. Con justa razón, sabiendo que no habían hecho nada, ni Ziehl ni Neelsen osaron hacer publicación alguna: el nombre de la tinción, como hoy la conocemos, nació de una simple nota al pie de una página, en una publicación que Johne hiciera en $1885^{11}$. ¡Jamás una eterna fama se edificó sobre bases más débiles! 
Muchos otros ejemplos podríamos agregar, pero la injusticia de este último nos ha dejado tan anonadados, que renunciamos, por el momento, a continuar.

\section{Bibliografía}

1.- Hitchens P, Leikind A M. The introduction of agaragar into bacteriology. J Bacteriol 1939; 37: 485-93.

2.- Merlino C P. Bartolomeo Bizio's letter to the most eminent priest, angelo Bellani, concerning the phenomenon of the red-colored polenta (translated from the italian). J Bacteriol 1924; 9: 527-43.

3.- Gaughran E R. From superstition to science: the history of a bacterium. Trans N Y Acad Sci 1969; 31: 3-24.

4.- Koch R. La etiología de la tuberculosis y otros trabajos. Ed. Universitaria, Buenos Aires 1965; 49-86.
5.- Behring E A von, Kitasato S. Uber die tetanusimmunizazione. Deutsch Med Wschr 1890; 16: 11-3.

6.- Povitzky O G. On the toxin production by Corynebacterium diphtheriae. J Immunol 1929; 16: 421-8.

7.- Howard-Jones N. Gelsenkirchen typhoid epidemic of 1901, and the dead hand of Max von Pettenkofer. Br Med J 1973; 103-5.

8.- Austrian R. The Gram stain and the etiology of lobar pneumonia, an historical note. Bacteriol Rev 1960; 24: $261-5$.

9.- Gram H C. Uber die isolierte Farbung der Schizomycetes in Schnitt und Trocken praparaten. Fortscher Med 1884; 2 (6): 185-9.

10.- Thoint L H, Masselin E J. Précis de microbiologia. G Mason et fils, Paris 1889; 148.

11.- Johne A. Die Geschichte der tuberkulose. Fortschr Med 1883; 3: 198-200. 